\title{
Meta-Analysis the Effect of Obesity and Stress on Menstrual Cycle Disorder
}

\author{
Lutfi Annarahayu1), Yulia Lanti Retno Dewi²), Rita Benya Adriyani3) \\ ${ }^{1)}$ Masters Program in Public Health,Universitas Sebelas Maret \\ 2)Faculty of Medicine,Universitas Sebelas Maret \\ 3)Health Polytechnics, Ministry of Health Surakarta
}

\section{ABSTRACT}

Background: There are many factors that influence menstrual patterns to become irregular, including stress and obesity. Menstrual cycle irregularities can have a serious impact on women's health, which will affect the metabolic, fertility, sexual and reproductive systems. This study aims to analyze the influence of obesity and stress on menstrual cycle disorders with a meta-analysis study.

Subjects and Method: This study is a systematic study and meta-analysis, with the following PICO, Population $=$ women of childbearing age. Intervention = obesity and stress. Comparison $=$ not obese and not stressed. Outcome $=$ disruption of the menstrual cycle. The articles used in this study were obtained from several databases, including PubMed, ScienceDirect and Google Scholar. The keywords used are "menstrual disorder and obesity and stress", "obesity and menstrual irregularity", "obesity OR stress AND menstrual irregularity OR cross sectional study". The articles included in this study are full text articles with a cross sectional study design. Articles were collected using
PRISMA flow diagrams. Articles were analyzed using the Review Manager 5.3 application.

Results: Meta-analysis of 8 observational studies showed that obese women were 4 times more likely to have menstrual cycle disorders than normal weight $(\mathrm{aOR}=4.19 ; 95 \% \mathrm{CI}=1.99$ to $8.84 ; \mathrm{p}=0.002)$. Meta-analysis of 6 observational studies showed that women with stress had a risk of experiencing menstrual cycle disorders 1.28 times compared to women who did not experience stress $(\mathrm{aOR}=1.28 ; 95 \% \mathrm{CI}=1.13$ to $1.45 ; \mathrm{p}=0.001$ ).

Conclusion: Obesity and stress affect menstrual cycle disorders.

Keywords: obesity, stress, menstrual cycle disorders, meta-analysis

\section{Correspondence:}

Lutfi Annarahayu. Masters Program in Public Health, Universitas Sebelas Maret. Jl. Ir. Sutami 36A, Surakarta 57126, Central Java. Email: Lutfi.annarahayu@student.uns.ac.id. Mobile: 081910979054 .

Cite this as:

Annarahayu L, Dewi YLR, Adriyani RB (2021). Meta-Analysis the Effect of Obesity and Stress on Menstrual Cycle Disorder. J Matern Child Health. 06(04): 423-435. https://doi.org/10.26911/thejmch.2021.06.04.04. Journal of Maternal and Child Health is licensed under a Creative Commons Attribution-NonCommercial-ShareAlike 4.o International License.

\section{BACKGROUND}

Menstruation is a complex process involving several hormones, sexual organs and the nervous system. Hormones have an important influence on menstruation, if the hormones are not balanced then the cycle will be disrupted. The menstrual cycle is a clinical sign of female reproductive function (Diaz et al., 2006). Menstrual cycle length is known as a predictor of health such as breast cancer and cardiovascular risk factors (Chavez and MacGregor et al., 2005).

There are many factors that influence menstrual patterns to become irregular, including stress, hormonal imbalance, thyroid disorders, obesity or weight gain, polycystic ovary disease, diabetes, metabolic 
syndrome, medication, environment, behavior and lifestyle factors. Irregularities in the menstrual cycle can seriously impact a woman's immediate and long-term health causing disturbing symptoms that affect metabolism, sleep, fertility, sexuality, reproductive life, and more (Sommer et al., 2017; Ganesan et al., 2019) .

Abnormal menstrual cycles are also associated with decreased fertility. The distance of the menstrual cycle is different for each woman, generally ranging from $15^{-}$ 45 days with an average of 28 days and the duration ranging from 2-8 days, an average of 4-6 days with blood released ranging from 60-80 $\mathrm{ml}$ per cycle (Prathita et al., 2017). Disorders of the menstrual cycle or irregularities are a major gynecological problem among women, especially adolescents and a source of anxiety for them and their families (Ali Abdella et al., 2016). According to a report by the World Health Organization (WHO), the prevalence of menstrual cycle disorders in women is around $45 \%$ (2012). A survey reported that about $64 \%$ of girls had at least one problem related to menstruation (Nath and Garg, 2008). The prevalence of menstrual disorders in India was recorded at $87 \%$. Various types of menstrual disorders include menstrual irregularities, menorrhagia, polimenorrhea, oligomenorrhea, dysmenorrhea, and others (Campbell and McGrath, 1997).

A person is said to be obese if he has a BMI $>30 \mathrm{~kg} / \mathrm{m}^{2}$ (WHO, 2020). Obesity is a serious public health problem worldwide because obesity plays a role in increasing morbidity and mortality. In 2016 more than 1.9 billion adults aged $>18$ years were overweight and $>650$ million of them were obese. The percentage of adolescents aged 12-19 years who are obese increased from $5 \%$ to $21 \%$ in $1975-2016$. More than 340 million children and adolescents aged 5-19 years were overweight or obese in 2016. The percentage of obese children and adolescents with female gender was $6 \%$ and male was $8 \%$ (WHO, 2020).

WHO data in 2016, globally there are about 35 million people who experience depression, 60 million people with bipolar disorder, 21 million people with schizophrenia, and 47.5 million people with dementia. The results of the 2018 Basic Health Research show that the prevalence of mental disorders as indicated by symptoms of depression at the age of 15 years and over reaches 6.1\% (Ministry of Health of the Republic of Indonesia, 2019a).

Based on an analysis of 22 studies involving 144,000 participants, it was found that obese adolescent girls were $44 \%$ more likely to develop depression or be diagnosed with depression in the future (Ministry of Health, 2019b). Stress levels can interfere with reproductive function which will stimulate the hypothalamus to release the hormone CRH which works antagonistically with GnRH so that GnRH levels decrease which causes disruption of the menstrual cycle (Sari and Setiarini, 2013).

Based on the high incidence of menstrual cycle disorders, obesity and stress experienced by women at this time, the researchers are interested in studying the effect of obesity, stress on menstrual cycle disorders. Researchers used a systematic review approach to relevant studies using meta-analysis to clearly identify the magnitude of the influence of obesity and stress on menstrual cycle disorders.

\section{SUBJECTS AND METHOD}

\section{Study Design}

The study design used in this research is a systematic review and meta-analysis, using PRISMA flow diagram guidelines. Article searches were conducted using journal 
databases including: PubMed, Google Scholar and Science Direct. The keywords used are "menstrual disorder", "menstrual disorder and obesity and stress", "obesity and menstrual irregularity", "stress and menstrual disorder", "obesity or stress or menstrual irregularity or cross sectional study", "obesity or stress or menstrual disorder or adjusted odd ratio".

\section{Inclusion Criteria}

In this study, the inclusion criteria were articles that used an observational study design, namely cross-sectional, articles in English, the analysis used was multivariate with adjusted odds ratio, the research subjects were women of childbearing age, the intervention was obesity and stress and the outcome was impaired menstrual cycle.

\section{Exclusion Criteria}

Exclusion criteria in this study include articles published not in full text before 2000 and in languages other than English.

\section{Operational Definition of Variable}

In formulating research problems, PICO is used. Population is women of childbearing age. Intervention is obesity and stress, with comparison that is not obesity and not stress and outcomes are menstrual cycle disorders

Menstrual cycle is periodic and cyclic bleeding originating from the uterus that is physiological in nature accompanied by the shedding of the endometrial wall that occurs in women of reproductive age

Obesity is a very high accumulation of fat in the body. Characterized by BMI values > $30 \mathrm{~kg} / \mathrm{m} 2$
Stress. The body's reaction/response to psychosocial stressors (mental stresses/life burdens).

\section{Research Instrument}

An assessment of the quality of research articles was carried out using the Critical Appraisal Checklist for Cross Sectional Study from the Center for Evidence Based Management (2014).

\section{Data Analysis}

The Review Manager application (RevMen 5.3) was used in analyzing the data in this study. The results of data analysis are in the form of effect size values and study heterogeneity which later on the results of the analyzed data are interpreted in the form of forest plots and funnel plots.

\section{RESULTS}

The process of searching for articles by searching through databases with journals can be seen in Figure 1. There were 1278 articles identified from the databased, after the deletion process of published articles, 184 articles were found with 130 of them eligible for a full text review. Articles were excluded for several reasons, so that 14 articles were included in the synthesis and meta-analysis studies.

Research from primary studies related to the effect of obesity and stress on menstrual cycle disorders consists of 14 studies originating from 9 studies from the Asian continent, 4 studies from the European continent, and 1 study from the Australian continent. 
Annarahayu et al./ The Effect of Obesity and Stress on Menstrual Cycle Disorder

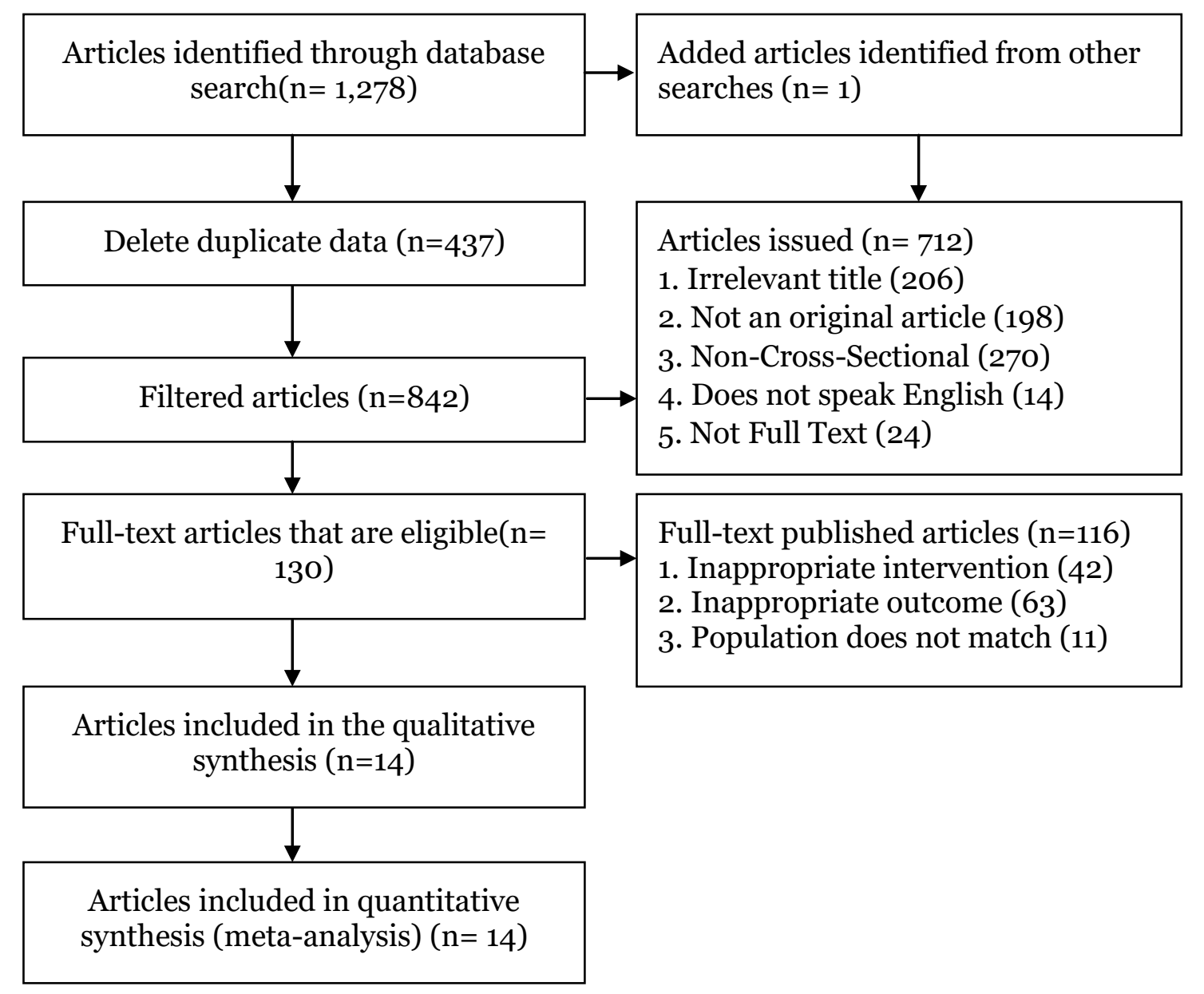

Figure 1. PRISMA flow diagram 
Annarahayu et al./ The Effect of Obesity and Stress on Menstrual Cycle Disorder

\section{Table 1. Assessment of Study Quality}

\begin{tabular}{|c|c|c|c|c|c|c|c|c|c|c|c|c|c|}
\hline Publication & $\begin{array}{l}\text { Rese- } \\
\text { arch ob- } \\
\text { jectives/ } \\
\text { focus }\end{array}$ & $\begin{array}{l}\text { Cross } \\
\text {-sec- } \\
\text { tional }\end{array}$ & Method & $\begin{array}{l}\text { Selec- } \\
\text { tion } \\
\text { Bias }\end{array}$ & $\begin{array}{l}\text { Repre- } \\
\text { sentive } \\
\text { sample }\end{array}$ & $\begin{array}{l}\text { Sample } \\
\text { size }\end{array}$ & $\begin{array}{l}\text { Res- } \\
\text { ponse } \\
\text { achieved }\end{array}$ & $\begin{array}{l}\text { Rese- } \\
\text { arch ins- } \\
\text { trument }\end{array}$ & $\begin{array}{l}\text { Signi- } \\
\text { ficant } \\
\text { statis- } \\
\text { tics }\end{array}$ & $\begin{array}{l}95 \% \\
\text { CI }\end{array}$ & $\begin{array}{l}\text { Conf } \\
\text { oun } \\
\text { ding }\end{array}$ & $\begin{array}{l}\text { Results } \\
\text { can be } \\
\text { applied }\end{array}$ & Total \\
\hline $\begin{array}{l}\text { Reavey et al. } \\
2020\end{array}$ & 1 & 1 & 1 & $\mathrm{O}$ & 1 & $\mathrm{O}$ & 0 & 1 & 1 & 1 & 1 & 1 & 8 \\
\hline $\begin{array}{l}\text { Castillo-Martínez } \\
\text { et al. } 2003\end{array}$ & 1 & 1 & 1 & $\mathrm{O}$ & 1 & $\mathrm{O}$ & $\mathrm{O}$ & 1 & 1 & 1 & 1 & 1 & 8 \\
\hline Zhou et al. 2020 & 1 & 1 & 1 & $\mathrm{O}$ & 1 & $\mathrm{O}$ & O & 1 & 1 & 1 & 1 & 1 & 8 \\
\hline Chen et al. 2020 & 1 & 1 & 1 & o & 1 & $\mathrm{O}$ & $\mathrm{O}$ & 1 & 1 & 1 & 1 & 1 & 8 \\
\hline $\begin{array}{l}\text { Ganesan et al. } \\
2019\end{array}$ & 1 & 1 & 1 & o & 1 & O & O & 1 & 1 & 1 & 1 & 1 & 8 \\
\hline seif et al. 2015 & 1 & 1 & 1 & $\mathrm{O}$ & 1 & $\mathrm{O}$ & O & 1 & 1 & 1 & 1 & 1 & 8 \\
\hline Wei et al. 2009 & 1 & 1 & 1 & $\mathrm{O}$ & 1 & $\mathrm{O}$ & O & 1 & 1 & 1 & 1 & 1 & 8 \\
\hline Chang et al. 2009 & 1 & 1 & 1 & o & 1 & 0 & 0 & 1 & 1 & 1 & 1 & 1 & 8 \\
\hline Lin et al. 2007 & 1 & 1 & 1 & o & 1 & $\mathrm{O}$ & $\mathrm{O}$ & 1 & 1 & 1 & 1 & 1 & 8 \\
\hline $\begin{array}{l}\text { Yamamoto et al. } \\
2009\end{array}$ & 1 & 1 & 1 & o & 1 & o & o & 1 & 1 & 1 & 1 & 1 & 8 \\
\hline Chang et al. 2009 & 1 & 1 & 1 & $\mathrm{O}$ & 1 & $\mathrm{O}$ & O & 1 & 1 & 1 & 1 & 1 & 8 \\
\hline Palm et al. 2014 & 1 & 1 & 1 & $\mathrm{O}$ & 1 & $\mathrm{O}$ & 0 & 1 & 1 & 1 & 1 & 1 & 8 \\
\hline $\begin{array}{l}\text { Rafique et al. } \\
2018\end{array}$ & 1 & 1 & 1 & $\mathrm{O}$ & 1 & o & o & 1 & 1 & 1 & 1 & 1 & 8 \\
\hline Yu et al. 2016 & 1 & 1 & 1 & $\mathrm{O}$ & 1 & $\mathrm{O}$ & $\mathrm{O}$ & 1 & 1 & 1 & 1 & 1 & 8 \\
\hline
\end{tabular}

Note:

Yes $=1$ No $=0$ 
Table 2. Description of the primary study of the effect of obesity on menstrual cycle disorders included in the meta-analysis

\begin{tabular}{|c|c|c|c|c|c|c|c|}
\hline Author (year) & Country & Study Design & Sample & $\begin{array}{c}\mathbf{P} \\
\text { Population }\end{array}$ & $\begin{array}{c}\text { I } \\
\text { Intervention }\end{array}$ & $\begin{array}{c}\mathrm{C} \\
\text { Comparison }\end{array}$ & $\begin{array}{c}\text { O } \\
\text { Outcome }\end{array}$ \\
\hline Reavey et al (2020) & The UK & Cross-sectional & 358 & $\begin{array}{l}\text { Women of } \\
\text { reproductive age }\end{array}$ & Obesity & Not obese & Menstrual cycle disorders \\
\hline $\begin{array}{l}\text { Castillo-Martínez et al. } \\
\text { (2003) }\end{array}$ & Mexico & Cross-sectional & 120 & $\begin{array}{l}\text { Women of } \\
\text { reproductive age }\end{array}$ & Obesity & Not obese & Menstrual cycle disorders \\
\hline Zhou Xinyu et al. (2020) & China & Cross-sectional & 1423 & $\begin{array}{l}\text { Women of } \\
\text { reproductive age }\end{array}$ & Obesity & Not obese & Menstrual cycle disorders \\
\hline Chen Xueyu et al. (2020) & China & Cross-sectional & 5,373 & $\begin{array}{l}\text { Women of } \\
\text { reproductive age }\end{array}$ & Obesity & Not obese & Menstrual cycle disorders \\
\hline Ganesan et al. (2019) & India & Cross-sectional & 163 & $\begin{array}{l}\text { Women of } \\
\text { reproductive age }\end{array}$ & Obesity & Not obese & Menstrual cycle disorders \\
\hline Seif et al(2015) & English & Cross-sectional & 11,791 & $\begin{array}{l}\text { Women of } \\
\text { reproductive age }\end{array}$ & Obesity & Not obese & Menstrual cycle disorders \\
\hline Wei Shuying et al. (2009) & Australia & Cross-sectional & 726 & $\begin{array}{l}\text { Women of } \\
\text { reproductive age }\end{array}$ & Obesity & Not obese & Menstrual cycle disorders \\
\hline Chang Pei et al. (2009) & Taiwan & Cross-sectional & 1,095 & $\begin{array}{l}\text { Women of } \\
\text { reproductive age }\end{array}$ & Obesity & Not obese & Menstrual cycle disorders \\
\hline
\end{tabular}

Table 3. Description of the primary study of the effect of stress on menstrual cycle disorders included in the meta-analysis

\begin{tabular}{|c|c|c|c|c|c|c|c|}
\hline Author (year) & Country & Study Design & Sample & $\begin{array}{c}\mathbf{P} \\
\text { Population } \\
\end{array}$ & $\begin{array}{c}\text { I } \\
\text { Intervention }\end{array}$ & $\begin{array}{c}\mathrm{C} \\
\text { Comparison }\end{array}$ & $\begin{array}{c}\mathbf{O} \\
\text { Outcome }\end{array}$ \\
\hline Lin Hsin et al. (2007) & Taiwan & Cross-sectional & 746 & $\begin{array}{l}\text { Women of } \\
\text { reproductive age }\end{array}$ & Stressed & Unstressed & Menstrual cycle disorders \\
\hline Yamamoto.K et al. (2009) & Japan & Cross-sectional & 264 & $\begin{array}{l}\text { Women of } \\
\text { reproductive age }\end{array}$ & Stressed & Unstressed & Menstrual cycle disorders \\
\hline Chang Pei et al. (2009) & Taiwan & Cross-sectional & 1095 & $\begin{array}{l}\text { Women of } \\
\text { reproductive age }\end{array}$ & Stressed & Unstressed & Menstrual cycle disorders \\
\hline Palm Simona et al. (2014) & Switzerland & Cross-sectional & 696 & $\begin{array}{l}\text { Women of } \\
\text { reproductive age }\end{array}$ & Stressed & Unstressed & Menstrual cycle disorders \\
\hline Rafique $\mathrm{N}$ et al. (2018) & Arab & Cross-sectional & 738 & $\begin{array}{l}\text { Women of } \\
\text { reproductive age }\end{array}$ & Stressed & Unstressed & Menstrual cycle disorders \\
\hline Yu Mi et al(2016) & Korea & Cross-sectional & 808 & $\begin{array}{l}\text { Women of } \\
\text { reproductive age }\end{array}$ & Stressed & Unstressed & Menstrual cycle disorders \\
\hline
\end{tabular}


Annarahayu et al./ The Effect of Obesity and Stress on Menstrual Cycle Disorder

\section{The effect of obesity on menstrual cycle disorders}

Research related to the effect of obesity on menstrual cycle disorders comes from the continents of Asia, Europe and Australia, consisting of various countries including the UK, China, Taiwan, India and Australia. The description of each study can be seen in Table 2.

\section{a. Forest Plot}

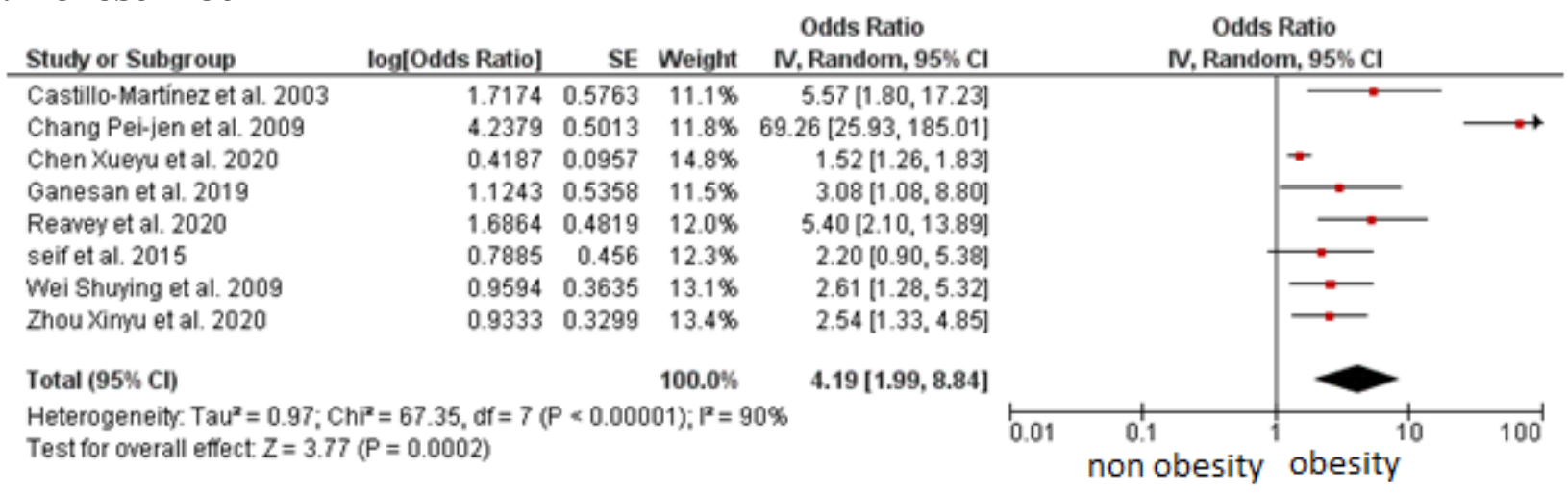

Figure 2. Forest plot meta-analysis effect of obesity and menstrual cycle disorders

The forest plot provides a summary of the data entered and gives weights for each study, effect sizes, methods and models used to perform the meta-analysis, confidence intervals used, impact estimates from each study, overall effect estimates, and statistical significance of the analysis. Interpretation of the results of the metaanalysis process can be seen through the forest plot. Figure 2 shows that there is an

\section{b. Funnel Plot}

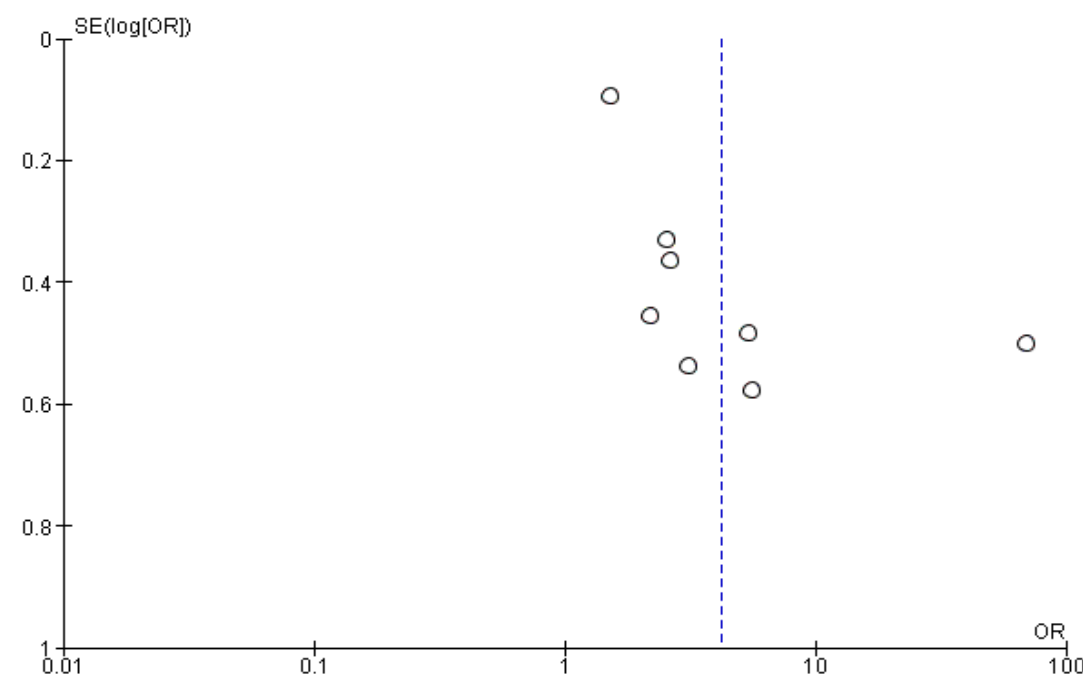

Figure 3. Funnel plot meta-analysis of the influence of obesity against cycle disturbance effect of obesity on the risk of experiencing menstrual cycle disorders. Obese women have a risk of experiencing menstrual cycle disorders 4 times compared to normal weight $(\mathrm{aOR}=4.19 ; 95 \% \mathrm{CI}=1.99$ to 8.84 ; $\mathrm{p}=0.002)$. The heterogeneity of the study data shows $\mathrm{I}^{2}=90 \%$ so that the distribution of the data is declared heterogeneous (random effect model). 
Annarahayu et al./ The Effect of Obesity and Stress on Menstrual Cycle Disorder

A funnel plot is a plot that depicts the approximate size of the effect of each study on the estimate of its accuracy which is usually the standard error.

Figure 3 shows that there is an asymmetrical picture in the funnel plot which indicates there is a slight publication bias in the primary study with a small sample size, which overestimates the true effect, as evidenced by there are 3 plots on the right, 4 plots on the left.

2. The relationship between stress and menstrual cycle disorders

Research related to the effect of stress on menstrual cycle disorders comes from the continents of Asia and Europe, consisting of Taiwan, Switzerland, Arabia, Japan and Korea. An overview of each study can be seen in Table 3.

\section{a. ForestPlot}

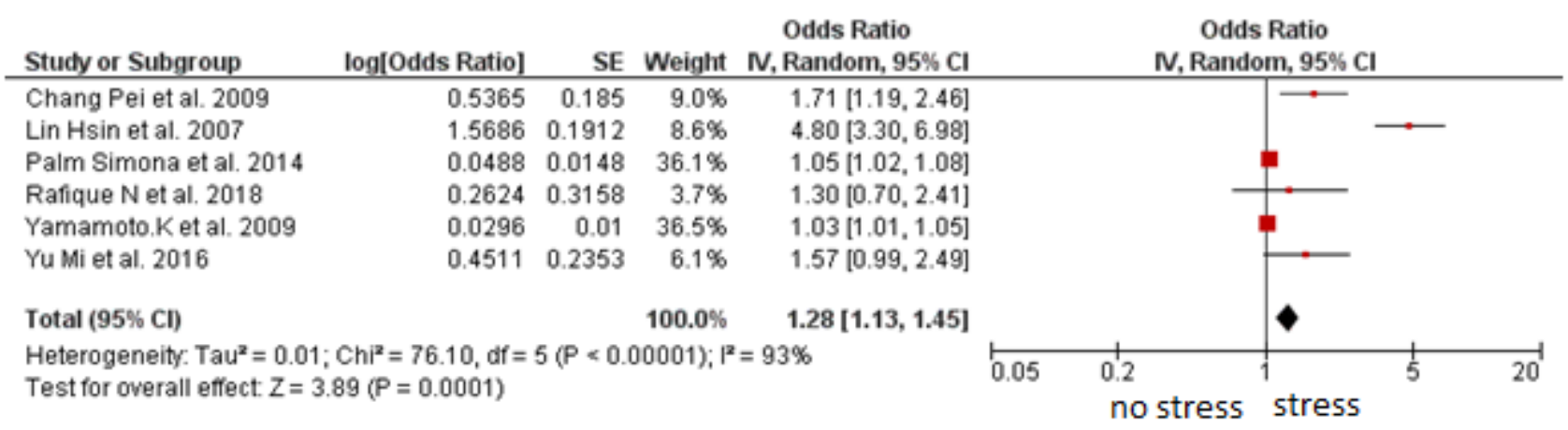

\section{Figure 4. Forest plot meta-analysis effect of stress and menstrual cycle disorders}

The interpretation of the results of the metaanalysis of the relationship between obesity and the incidence of PCOS in women of childbearing age can be seen through the forest plot. Figure 4 shows that there is an effect of stress on the risk of experiencing menstrual cycle disorders. Women with stress

\section{b. Funnel Plot}

had a risk of experiencing menstrual cycle disorders 1.28 times compared to women who did not experience stress (aOR $=1.28 ; 95 \% \mathrm{CI}$ $=1.13$ to $1.45 ; \mathrm{p}=0.001)$. The heterogeneity of the research data shows I2 $=93 \%$ so that the distribution of the data is declared heterogeneous (random effect model).

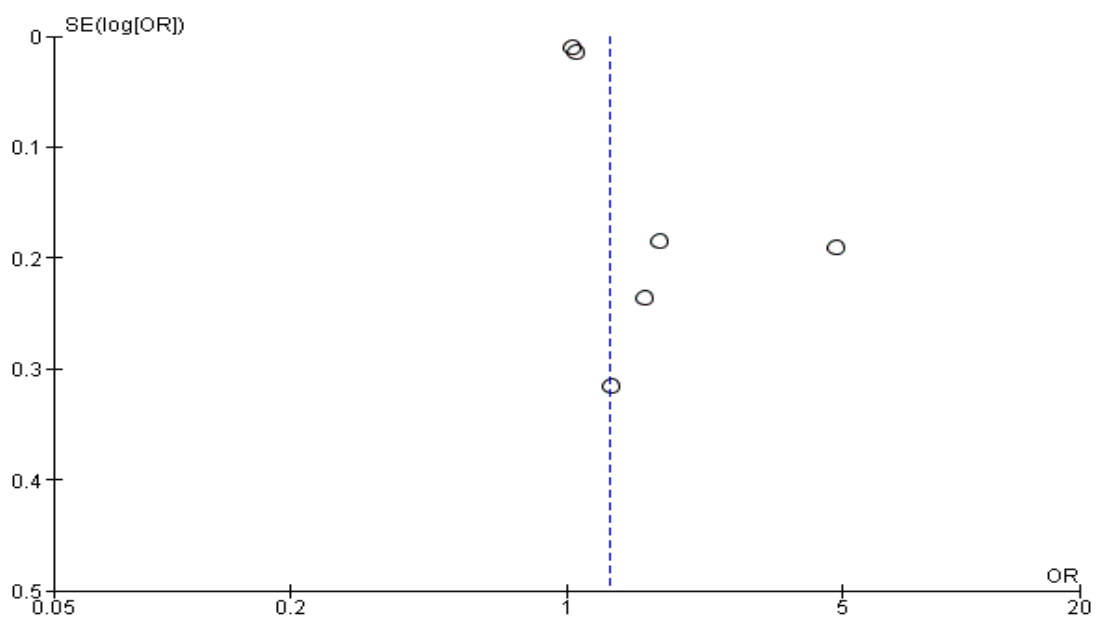

Figure 5. Funnel plot meta-analysis of the relationship between stress and menstrual cycle disorders 
Based on Figure 5 funnel plot of the effect of stress on menstrual cycle disorders, there is an asymmetrical picture in the funnel plot which indicates there is a slight publication bias in the primary study with a small sample size, which overestimates the effect.

\section{DISCUSSION}

This systematic review and meta-analysis research is about the effect of obesity and stress on menstrual cycle disorders. The independent variable in this study was obesity and the dependent variable analyzed was menstrual cycle disorders.

This meta-analysis study uses research that controls confounding factors because the research involved is a study that uses multivariate analysis and the statistical results reported are adjusted odds ratio (aOR). The combined estimate of the relationship between obesity and stress on menstrual cycle disorders was processed using the RevMan 5.3 application. The results of the systematic study and metaanalysis are presented in the form of forest plots and funnel plots.

\section{The effect of obesity on menstrual cycle disorders}

There are 8 research articles from various countries using observational methods that can be used as sources for this metaanalysis research. The results of the forest plot show that there is an effect of obesity on the risk of experiencing menstrual cycle disorders. Obese women had a risk of experiencing menstrual cycle disorders 4 times compared to normal weight $(\mathrm{aOR}=4.19$; 95\% CI= 1.99 to $8.84 ; \mathrm{p}=0.002$ ).

This is in line with Reavey et al, (2020) which found that women with obesity had an increased risk of menstrual cycle lengthening 5.4 times compared to women with normal weight. Increased BMI will have an impact on endometrial func- tion, increasing estrogen levels as a result of peripheral conversion of androgens by the adipose tissue aromatase enzyme.

Ganesan et al (2019) also conducted a similar study with the results that obese women had a 3.08 times risk of experiencing irregular menstrual patterns compared to women with normal weight. This study found a very strong and significant relationship between BMI and irregular menstrual patterns similar to various studies around the world. If the BMI is kept within the normal range or even switched to a lower weight category by adapting simple but proven effective measures like physical activity, dietary changes, etc., we can regulate the menstrual cycle to some extent without needing any medication.

A high percentage of body fat can cause an increase in androgens which play a role in producing estrogen with the help of the aromatase enzyme which converts androgens into estrogen in granulosa cells and fat tissue, so that with increasing body fat, estrogen increases which can cause hormonal imbalances and vice versa, the percentage of body fat Low levels cause a decrease in the production of the hormone estrogen so that it disrupts the balance and causes menstrual cycle disorders (Septian, 2017).

\section{The effect of stress on menstrual cycle disorders}

There are 6 cross-sectional research articles as a source of meta-analysis related to the effect of stress on menstrual cycle disorders. The results of the forest plot of research articles with this cross-sectional study showed that women with stress had 1.28 times the risk compared to women who were not stressed and the results were statistically significant $(\mathrm{aOR}=1.28 ; 95 \%$ $\mathrm{CI}=1.13$ to 1,$45 ; \mathrm{p}=0.001)$.

The results of this study are supported by Chan Pei et al (2009) which states that 
women with stress are 1.7 times more likely to experience menstrual cycle disorders compared to women who are not stressed. Psychological stress includes stressors in life, psychological stress or work stress resulting in longer cycles, cycle variability and pain during menstruation; However, women with excessive work pressure have also been shown to have shorter cycles. One of the mechanisms linking stress to menstrual function occurs through impaired function of the hypothalamic-pituitaryadrenal axis of the body's stress response so that glucocorticoids have a reciprocal interaction with ovarian hormones that will affect a woman's menstrual cycle.

Lin Hsin et al. (2007) also conducted a similar study on nurses in 4 public hospitals in Taiwan. Nurses' menstrual cycle was considered abnormal if it was less than 24 days or longer than 35 days. Demographic variables for logistic regression analysis included: self-perceived work stress level, age, body mass index (BMI), marital status, pregnancy history. However, not having a partner, having never been pregnant and working for less than 5 years were statistically associated with longer and irregular menstrual cycles. In addition, nurses who worked more than 40 hours per week were more at risk of experiencing irregular menstrual cycles $(\mathrm{OR}=1.5,95 \%$ $\mathrm{CI}=1.1$ to $2.1, \mathrm{p}=0.029)$. After adjusting for work stress, age, BMI, marital status, pregnancy history, occupation and working hours, only those with high levels of job stress had a statistically significant risk of irregular menstrual cycles $(\mathrm{AOR}=4.8 ; 95 \%$ $\mathrm{CI}=3.3$ to $7.2, \mathrm{p}<0.001)$. Work stress can disrupt endocrine function and biological rhythms that can cause irregular menstrual cycles, changes in abnormal menstrual bleeding patterns.

A study by Yamamoto et al. (2009) involved 264 students in Japan. Lifestyle factors such as smoking, alcohol consumption, exercise, dietary habits, physical factors such as body mass index (BMI), and menstrual factors such as age at menarche and menstrual duration are associated with premenstrual symptoms, menstrual pain, and irregular menstrual cycles. Menstrual cycle was defined as the period between the first day of menstrual flow and the day immediately before the next menstrual flow. Stress scores and BMI were shown to be significant predictors of experiencing irregular menstrual cycles. Students who had higher stress scores were more likely to experience irregular menstrual cycles. Students with high stress scores have a risk of 1.03 times experiencing irregular menstrual cycles compared to students with low stress scores.

In women who experience stress will occur conditions that disrupt homeostasis. Reproductive status is a reflection of a person's psychological state, if there is an increase in exposure to stress, reproductive function will automatically decrease to maintain body homeostasis. The stress system is regulated by the hypothalamic pituitary adrenal (HPA) axis and the autonomic system. The main mediators of the stress system include Cortocoptopin Relaxing Hormone (CRH), glicorcorticoids, and beta endorphins. $\mathrm{CRH}$ has various tissues such as ovaries, endometrium, hypothalamus and inflammatory tissue. Increased production of $\mathrm{CRH}$ and cortisol causes the restriction of GnRH secretion to decrease ovulation. This decrease in ovulation will affect the length of the proliferation and secretion period so that it affects the menstrual cycle (Rakhmawati, 2012).

\section{AUTHOR CONTRIBUTION}

Lutfi Annarahayu is the main researcher who chooses the topic, conducts a search for data collection in this study. Yulia Lanti 
Annarahayu et al./ The Effect of Obesity and Stress on Menstrual Cycle Disorder

and Rita Benya Andriani conducted data analysis and review of research documents.

\section{FUNDING AND SPONSORSHIP}

This study is self-funded.

\section{CONFLICT OF INTEREST}

There is no conflict of interest in this study.

\section{ACKNOWLEDGEMENT}

The researcher would like to thank all those who have helped in the preparation of this article and also thank the database providers PubMed, ScienceDirect, and Google Scholar.

\section{REFERENCE}

Abdella ADNH, Abd-Elhalim A, Fathy Attia, D. A. M. (2016). The body mass index and menstrual problems among adolescent students. IOSR J Nurs Health Sci. 05(04): 13-21. https://doi.org/10.9790/1959-0504021321.

Campbell MA, Mcgrath PJ (1997). Use of medication by adolescents for the management of menstrual discomfort. Arch Pediatr Adolesc Med. 151(9): 905-13. https://doi.org/10.1001/archpedi.1997.02170460043007.

Castillo-Martínez L, López-Alvarenga JC, Villa AR, González-Barranco J (2003). Menstrual cycle length disorders in 18 - to 40-y-old obese women. Nutr. 19(4): 317-320. https://doi.org/10.1016/So899-9007(02)00998-X.

Center for Evidence Based Management. (2014). Critical appraisal checklist for cross-sectional study.

Chang PJ, Chen PC, Hsieh CJ, Chiu LT (2009). Risk factors on the menstrual cycle of healthy Taiwanese college nursing students. Aust N Z J Obstet Gynaecol. 49(6): 689-694. https://doi.org/10.1111/j.1479-828X.2009.01- 097.x.

Chavez-MacGregor M, Elias SG, OnlandMoret NC, Van DSYT, Van GCH, Monninkhof E, Grobbee DE, Peeters PHM (2005). Postmenopausal breast cancer risk and cumulative number of menstrual cycles. Cancer Epidemiol Biomarkers Prev. 14(4): 799-804. https://doi.org/10.1158/1055-9965.EPI-04-0465.

Diaz A, Laufer MR, Breech LL (2006). Menstruation in girls and adolescents: Using the menstrual cycle as a vital sign. Pediatr. 118(5): 2245-2250. https://doi.org/10.1542/peds.20062481.

Ganesan DK, Krishnan GK, Chitharaj RR, Boopathirajan R (2019). A cross-sectional study on relationship between body mass index and menstrual irregularity among rural women in Tamil Nadu. Int J Community Med Public Health. 6(11): 4635. https://doi.org/10.18203/2394-6040.ijcmph20194561.

Kementrian Kesehatan RI (2019a). Profil Kesehatan Indonesia. Kementrian Kesehatan Republik Indonesia.

Kementrian Kesehatan RI (2019b). Remaja Putri yang Obesitas Berisiko Depresi (Obese Teenage Girls are at Risk for Depression). Kementrian Kesehatan Republik Indonesia.

Kumar S, Kelly AS (2017). Review of childhood obesity: From epidemiology, etiology, and comorbidities to clinical assessment and treatment. Mayo Clinic Proceedings. 92(2): 251-265. https://doi.org/10.1016/j.mayocp.201 6.09.017.

Lin HT, Lin LC, Shiao JSC (2007). The impact of self-perceived job stress on menstrual patterns among Taiwanese nurses. Industrial Health. 45(5): 709714. https://doi.org/10.2486/indhea- 
Annarahayu et al./ The Effect of Obesity and Stress on Menstrual Cycle Disorder

lth.45.709

Moreno LA, Mesana M, González-Gross M, Gil CM, Ortega FB, Fleta J, Wärnberg $\mathrm{J}$, et al. (2007). Body fat distribution reference standards in Spanish adolescents: The AVENA Study. Int J Obesity. 31(12): 1798-1805. https://doi.org/10.1038/sj.ijo.0803670

Murti, B. (2018). Prinsip dan Metode Riset Epidemiologi (Edisi V) (Principles and Methods of Epidemiological Research (V). (Universitas Sebelas Maret (ed.); V). Bintang Fajar Offset.

Nath A, Garg S (2008). Adolescent friendly health services in India: A need of the hour. Indian J Med Sci. 62(11): 465472. https://doi.org/10.4103/o019-5359.48461.

Palm-Fischbacher S, Ehlert U (2014). Dispositional resilience as a moderator of the relationship between chronic stress and irregular menstrual cycle. J of Psychosom Obstet Gynecol. 35(2): 42-50. https://doi.org/10.3109/0167482X.2014.912209.

Rad M, Sabzevary TM, Dehnavi MZ (2018). Association between menstrual disorders and obesity-related anthropometric indices in female high school students: A cross-sectional study. Int J School Health. 5(2): 1-8. https://doi.org/10.5812/intjsh.65716.

Rafique N, Al-Sheikh MH (2018). Prevalence of menstrual problems and their association with psychological stress in young female students studying health sciences. Saudi Med J. 39(1): 67-73. https://doi.org/10.15537/smj.2018.1.21438.

Rakhmawati A, Dieny FF (2013). Hubungan obesitas dengan kejadian gangguan siklus menstruasi pada wanita dewasa muda (The relationship between obesity and the incidence of menstrual cycle disorders in young adult women). J Nutr Coll. 2(1): 214222. https://doi.org/10.14710/jnc.v2i1.2106.

Reavey JJ, Duncan WC, Brito-Mutunayagam S, Reynolds RM, Critchley HOD (2020). Obesity and menstrual disorders. In Obesity and Gynecology. INC. https://doi.org/10.1016/b978-o12-817919-2.00019-X.

Seif MW, Diamond K, Nickkho-Amiry M (2015). Obesity and menstrual disorders. Best Prac Res: Clin Obstet Gynaecol. 29(4): 516-527. https://doi.org/10.1016/j.bpobgyn.2014.10.010.

Septian R, Ahaddini, Widyastuti N, Probosari E (2017). Konsumsi fitoestrogen, persen lemak tubuh dan siklus menstruasi pada wanita vegetarian (Phytoestrogen consumption, percent body fat and menstrual cycle in vegetarian women). J Nutr Coll. 6(2): 180-190.https://doi.org/10.14710/jnc.v6i2.16908.

Sommer M, Phillips-Howard PA, Mahon T, Zients S, Jones M, Caruso BA (2017). Beyond menstrual hygiene: Addressing vaginal bleeding throughout the life course in low and middle-income countries. BMJ Global Health. 2(2): 1-7. https://doi.org/10.1136/bmjgh2017-000405.

Wei S, Schmidt MD, Dwyer T, Norman RJ, Venn AJ (2009). Obesity and menstrual irregularity: Associations with SHBG, testosterone, and insulin. Obesity. 17(5): 1070-1076. https://doi.org/10.1038/oby.2008.641.

WHO (2020). Obesity and overweight. https://www.who.int/news-room/fact-sheets/detail/obesity-and-overweight.

Xueyu Chen, Tang Y, Chen Y, Feng H, Zhu C, Tong M, Chen Q (2020). Is body mass index associated with irregular menstruation: A questionnaire study? 
Annarahayu et al./ The Effect of Obesity and Stress on Menstrual Cycle Disorder

BMC Women's Health. 20(1): 4-9. https://doi.org/10.1186/s12905-02001085-4.

Yamamoto K, Okazaki A, Sakamoto Y, Funatsu M (2009). The relationship between premenstrual symptoms, menstrual pain, irregular menstrual cycles, and psychosocial stress among Japanese college students. J Physiol
Anthropol. 28(3): 129-136. https://doi.org/10.2114/jpa2.28.129.

Zhou X, Yang X (2020). Association between obesity and oligomenorrhea or irregular menstruation in Chinese women of childbearing age: a crosssectional study. Gynecol Endocrinol. 36(12): 1101-1105. https://doi.org/10.1080/09513590.2020.1803823. 